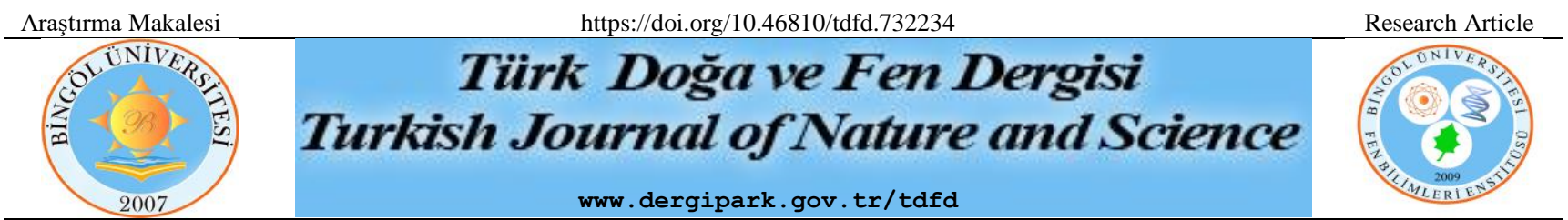

\title{
Screening of Antimicrobial Effect against Microorganisms Threatening to Human Health of the Endemic Plant; Centaurea saligna (C. Koch) Wagenitz from Turkey
}

\author{
PInar ERECEVIT SÖNMEZ ${ }^{1 *}$, Uğur ÇAKILCIOĞLU ${ }^{2}$ \\ ${ }^{1,2}$ Munzur University, Pertek Sakine Genç Vocational School, Department of Medical Services, Tunceli, Turkey \\ Pınar ERECEVIT SÖNMEZ ORCID No: 0000-0003-2389-0694 \\ Uğur ÇAKILCIOĞLU ORCID No: 0000-0002-3627-3604
}

*Corresponding author: pinarerecevit@hotmail.com,perecevit@munzur.edu.tr

(Alınış: 05.05.2020, Kabul: 22.09.2020, Online Yayınlanma: 23.10.2020)

\begin{abstract}
Keywords Centaurea saligna, Dermatophyte pathogens, Bacteria, Yeast, Antimicrobial effect
\end{abstract}

\begin{abstract}
In this study, the antimicrobial effect researched on microorganisms threatening to human health of extract including methanol of Centaurea saligna that is endemic and used for therapy of many diseases. For disk diffusion method, this related extract is highly effective on the gram negative bacteria by its $20.3 \pm 0.5 \mathrm{~mm}$ inhibition zone $(\mathrm{p}<0.001)$. Again to relation bacteria, gram positive bacteria are highly effective by $18.3 \pm 0.5 \mathrm{~mm}$ and $20.3 \pm 0.5 \mathrm{~mm}$ inhibition area $(\mathrm{p}<0.001)$. It has a effect against Candida species and Epidermophyton sp., the superficial skin infections are caused, by $9.6 \pm 0.5 \mathrm{~mm}$ and $13.6 \pm 1.5 \mathrm{~mm}$ inhibition area $(\mathrm{p}<0.01)$. On the other hand, for findings, this related extract is extremely effective against Trichophyton $\mathrm{sp}$. that is one of dermatophyte fungi by $24.6 \pm 1.5$ inhibition area $(\mathrm{p}<0.0001)$. This natural extract shows its antimicrobial effect namely, by minimal inhibition value (MIC): $6.25 \mu \mathrm{L}$ its lowest inhibition value against development of all the bacteria and dermatophyte fungi.

This plant has a potential to be a natural antimicrobial agent to be used as a medicine for human health and life quality.
\end{abstract}

\section{Türkiye de Yetişen Endemik Bitki; Centaurea saligna (C. Koch) Wagenitz’in İnsan Sağlı̆̆ını Tehdit Eden Mikroorganizmalara Karşı Antimikrobiyal Etkisinin Araştırılması}

Anahtar
Kelimeler
Centaurea
saligna,
Dermatofit
patojenler,
Bakteriler
Mayalar,
Antimikrobiyal
etki

Öz: Bu çalışmada endemik olarak yetişen ve birçok hastalığın tedavisinde kullanılan Centaurea saligna bitkisinin metanol ile hazırlanan ekstraktının insan sağlı̆̆ını tehdit eden mikroorganizmalar üzerindeki antimikrobiyal etkisi araştırılmıştır. Disk Difüzyon Metodu'na göre; Kullanılan ekstrakt gram negatif bakteriler üzerinde $20.3 \pm 0.5 \mathrm{~mm}$ inhibisyon bölgesi ile oldukça etkilidir $(\mathrm{p}<0.001)$. Yine bakterilerden gram pozitif bakteriler üzerinde; $18.3 \pm 0.5 \mathrm{~mm}$ inhibisyon bölgesi ve $20.3 \pm 0.5 \mathrm{~mm}$ inhibisyon bölgesi ile oldukça etkilidir ( $\mathrm{p}<0.001)$. Yüzeysel cilt enfeksiyolarına neden olan mantarlardan Candida suşlarında; $9.6 \pm 0.57 \mathrm{~mm}$ inhibisyon bölgesi ile dermatofit mantarlarından Epidermophyton sp. 'ye karşı 13.6 $\pm 1.5 \mathrm{~mm}$ inhibisyon bölgesi ile etkilidir $(\mathrm{p}<0.01)$. Diğer yandan; bu ilgili ekstraktın dermatofit mantarlarından biri olan Trichophyton sp'ye karşı $24.6 \pm 1.52 \mathrm{~mm}$ inhibisyon bölgesi ile son derece etkili olduğu bulunmuştur ( $\mathrm{p}<0.0001)$. Bu doğal ekstrakt antimikrobiyal etkisini tüm bakteri ve dermatofit mantarlarının gelişimine karşı en düşük inhibisyon değeri yani minimal inhibisyon değeri (MİC): $6.25 \mu \mathrm{L}$ ile gösterir.

$\mathrm{Bu}$ bitkinin insan hücrelerine karşı sitotoksisitesi daha önceki çalışmalarda araştırılmış olmakla birlikte $C$. saligna bitkisi insan sağlığı ve yaşam kalitesi üzerine ilaç olarak kullanılacak doğal bir antimikrobiyal ajan olma potansiyelindedir.

\section{INTRODUCTION}

To date, notable studies have been made to learn microorganisms and their control. Many important diseases are mainly cured with antibiotics and herbal medicines. On the other hand, improper use of antibiotics enabled carry out many pathogenic microorganisms to develop resistance against all known antibiotics. Due to these disadvantages, new 
antimicrobial agents need to be developed. It is estimated that there are approximately $250 \quad-500$ thousand plant species in the world, but very low amount of them are used as food by humans and animals. The medicinal herbs in Turkey have been shown to be a promising powerful source of antimicrobial agents [1].

A study used for the discovery of natural antimicrobial drugs from plants is based on the evaluation of traditional medicinal plant extracts as drugs [2].

Turkey is one of the richest in terms of endemism. As it is known, only plant species living on a certain flora on earth are called "endemic" and in this case it is defined as "endemism". C. saligna, Turkey is referred to as an endemic plant [3].

Centaurea L. (Asteraceae) genus, 114 of which are endemic, It is represented by 192 taxa in Turkey. It is known with vernacular names such as "peygamber çiçeği, zerdali dikeni, coban kaldiran, timur dikeni" in Turkey [4]. In this study, one (C. saligna) the minimum amount of Centaurea taxa endemic to Turkey are even designed to determine whether they are effective in inhibiting the growth of microorganisms that threaten human health [4].

Many species of the genus Centaurea L. have been traditionally used for the treatment of various diseases among the local people [5].

Centaurea species have been used for their antidandruff, antidiarrhoic, antirheumatic, antiinflammatory, choleretic, diuretic, digestive, stomachic, astringent, antipyretic, cytotoxic and antibacterial properties in folk medicine [6].

The genus Centaurea has been the subject of many antimicrobial and antioxidant activity properties [7-18].

Microsporum, Trichophyton and Epidermophyton species are dermatophyte pathogens that cause infections on the skin. Nondermatophyte fungi (eg Malassezia furfur in Tinea [pityriasis] versicolor) and Candida species that cause superficial skin infections are less common [19]. This study can be used as a natural remedy for healing of dermatophyte infections. The thing that makes out study different is that dermatophyte fungi which infect human skin, nails and hair was researched for the first time; besides, MIC experiment was performed as more comprehensive.

\section{MATERIAL AND METHODS}

\subsection{Screening of Antimicrobial Effect}

\subsubsection{Plant material}

Centaurea saligna (Asteraceae) was collected during appropriate vegetation (in June 2018) as the material from the Bingöl Kuruca village on northern slopes in the Turkey. This plant sample has been maintained in the Herbarium of Munzur University (UC - 144) in Tunceli, Turkey (UC - 144). The Flora of Turkey was utilized for the taxonomic diagnosis [20].The diagnosed plant was made suitable for grinding. The grinded plant $(5 \mathrm{~g})$ was treated in $20 \mathrm{~mL}$ methanol $(98.1 \%)$ solvent by keeping on a rotary shaker $(100 \mathrm{rpm})$ for $24 \mathrm{~h}$. Thus, the plant extract was obtained. These plant materials were filtered under suitable aseptic conditions and left at $4^{\circ} \mathrm{C}$ for further study. Then, $100 \mu \mathrm{L}\left(25 \mathrm{mg} \mathrm{L}^{-1}\right)$ of plant extracts were injected into $6 \mathrm{~mm}$ diameter (Schleicher \& S hüll No: 2668, Germany) blank antibiotic paper discs to try the test isolates separately.

\subsubsection{Microbial strain}

The bacteria (Escherichia coli ATCC 25922, Pseudomonas aeruginosa DSM 50071, Staphylococcus aureus COWAN 1, Bacillus megaterium DSM 32), yeasts (Candida albicans FMC 17, Candida glabrata ATCC 66032) and dermatophyte (Trichophyton sp., Epidermophyton sp.) were tested as species for the current study. The tested pathogens were taken by the Department of Biology, Firat University, Microbiology Laboratory, Elazig-Turkey.

\subsubsection{Antimicrobial sensitivity test}

The agar disc diffusion method was performed in order to detect antimicrobial effect. Mueller Hinton Agar, Yeast Malt Extract Agar and Sabouraud Dextrose Agar were prepared separately in erlen-meyer bottles under laboratory conditions and brought to $45-50^{\circ} \mathrm{C}$ pouring temperature, with the culture of microorganisms to be prepared as explained, will be added at the incidence of $\% 1\left(10^{6}\right.$ cells $\mathrm{mL}^{-1}$ of bacteria, $10^{4}$ cells $\mathrm{mL}^{-1}$ yeast and cells $\mathrm{mL}^{-1}$ dermatophyta fungi as per Mc Farland standard). $15 \mathrm{ml}$ medium by shaking well is poured in to sterile petri plates and homogenously distributed. The discs (6 $\mathrm{mm}$ diameter) with treated 10 microliters of plant extract were added to the appropriate agar media inoculated with microorganism. Then, petri dishes was stored at $4{ }^{0} \mathrm{C}$ or $2 \mathrm{~h}$. The cultivated petri dishes were left in the incubator at $37 \pm 0.1^{0} \mathrm{C}$ at $24 \mathrm{~h}$ for bacterial isolates and also at $25 \pm 0.1^{\circ} \mathrm{C}$ at $72 \mathrm{~h}$ for Candida strains and dermatophyte pathogens. The antibacterial, antifungal, antidermatophyta sensitivity of plant extract was evaluated by observing the inhibition area on the disks [21]. Micostatin and ampicillin sulbactam were used as positive control. Methanol injected discs were tested as negative control.

\subsubsection{Minimal inhibition concentration}

Minimal inhibitory concentrations (MIC) were detected using the Broth dilution assay. The cultures were obtained in Mueller Hinton Broth (Difco, Difco Laboratories, Detroit, MI, USA). The passages of microorganisms were prepared with 12-hour broth cultures and the passages were set at a blur of $0.5 \mathrm{Mc}$ Farland Standard. The plant sample was first rarefied to the maximum value $100 \mu \mathrm{L}$ to be evaluated, and then serial 2-fold subtilizations were acquired in a value serial from 6.25 to $100 \mu \mathrm{L}(1562-25000 \mu \mathrm{g})$ in $10 \mathrm{~mL}$ aseptic test tubes including nutrient broth for bacteria and sabouraud dextrose broth for yeast and dermatophyta 
fungi. MIC values of this plant against analyzed microorganisms were revealed with a micro-well dilution method [22]. The propagation of microorganisms was determined by an EL x 800 universal microtiter plate reader at $600 \mathrm{~nm}$ with optical density quantity. After incubation for $18-24 \mathrm{~h}$ at $37 \pm 10 \mathrm{C}$ for bacteria, $25 \pm 0.10 \mathrm{C}$ at $72 \mathrm{~h}$ for yeast and dermatophyte pathogens. It was defined as the smallest value of that sample for the nominal value of the plant material used to prevent proliferation of microorganisms. This is the last tube symbolization (mg mL-1) whose demectric is not microbial growth.

\subsection{Statistical Analysis}

Statistical comparisons were made between the extract and control groups (methanol, ampicillin sulbactam, micostatin) in relation to measurable preventive activity against bacteria, yeast and dermatophytes. SPSS soft ware was used for statistical evaluation (SPSS Inc., Chicago IL). The values were achieved by analysis of variance (ANOVA) and the lowest significant difference (LSD) tests were specified as mean \pm SE. $\mathrm{P}<0.0001$, $\mathrm{p}<0.001, \quad \mathrm{p}<0.01, \quad \mathrm{p}>0.05$ were evaluated for the variations between extract and control groups. $\mathrm{P}$ values given as footnotes below Table 1 and 2 were considered extremely effect, highly effect and moderately effect. This study was conducted in three repetition.

\section{RESULTS AND DISCUSSION}

The datas of the antimicrobial evaluation showed that this extract have strong effect against the tested microorganisms (Table 1-2). C. saligna extract has highly effective with $20.3 \pm 0.5 \mathrm{~mm}$ inhibition area on $E$. coli, $P$. aeruginosa from gram negative bacteria. In gram positive- bacteria; It is highyl effective in destroying the proliferation of $S$. aureus and B. megaterium, E. coli, $P$. aeruginosa with $18.3 \pm 0.5 \mathrm{~mm}$ inhibition area and $20.3 \pm 0.57 \mathrm{~mm}$ inhibition zone $(\mathrm{p}<0.001 ; \mathrm{d})$. In fungi; It is effect with $9.66 \pm 0.57 \mathrm{~mm}$ inhibition area against $C$. albicans, C. glabrata and with $13.6 \pm 1.5 \mathrm{~mm}$ inhibition area against Epidermophyton sp from dermatophyta fungi $(\mathrm{p}<0.01 ; \mathrm{c})$. On the other hand; It were found that this extract to be extremely effective with $24.6 \pm 1.5 \mathrm{~mm}$ inhibition area against Trichophyton $\mathrm{sp}$ from dermatophyta fungi ( $<<0.0001$; cd). In conclusion, antimicrobial feature of $C$. saligna is pretty high against bacteria, yeast and dermatophyte fungi compared to standard antibiotic and methanol.

The antimicrobial activity of this endemic plant extract in concentrations ranging from $100 \mu \mathrm{L}$ to $6.25 \mu \mathrm{L}$ of was evaluated against all of the tested microorganisms with MIC. Table 2. shows the MIC value of all pathogen microrganisms for this extract. The MIC values were in the range of $6.25 \mu \mathrm{L}$ to $12.25 \mu \mathrm{L}$ in average. Acording to this; the results showed good inhibitory effect with 6.25 $\mu \mathrm{L}$ for E. coli, S. aureus, B. megaterium, P. aeruginosa, Epidermophyton sp., Trichophyton sp. with $12.25 \mu \mathrm{L}$ for C. albicans, C. glabrata. So that means; this natural extract showed its antimicrobial affect at the lowest inhibition value tested against the development of all bacteria and dermatophyte fungi $(6.25 \mu \mathrm{L})$. This once again proved that this endemic extract, which we use with the MIC method, is very effective against the development of pathogenic microorganisms.

Table 1. Screening of antimicrobial effect of $C$. saligna by the agar disc diffusion method

Extract positive control; ampicillin sulbactam $(*)$ and mikostatin $(* *)$ $(120 \mu \mathrm{L}$ and $20 \mu \mathrm{g} / \mathrm{disc})$, the negative control; methanol. Inhibition zone > $20 \mathrm{~mm}$ (extremely effect; $\mathrm{p}<0.0001$; cd), 15 - $19 \mathrm{~mm}$ (highly effect; $\mathrm{p}<0.001 ; \mathrm{d}), 9-14 \mathrm{~mm}$ (effective; $\mathrm{p}<0.001 ; \mathrm{d}$ ), very low effect $(\mathrm{a}: \mathrm{p}>0.05)$

Table 2. The minimum inhibition value (MIC in $100 \mu \mathrm{L}$ ) of C. Saligna against the microorganisms

\begin{tabular}{|c|c|c|c|}
\hline \multirow{3}{*}{ Microorganisms } & \multicolumn{3}{|c|}{ Inhibition area $(\mathrm{mm})$} \\
\hline & \multirow[t]{2}{*}{ C.saligna } & \multicolumn{2}{|c|}{ Control } \\
\hline & & Methanol & $\begin{array}{c}\text { Standart } \\
\text { antibiotics }\end{array}$ \\
\hline E. coli & $20.3 \pm 0.5^{d}$ & $8.6 \pm 0.5^{\mathrm{c}}$ & $14.3 \pm 0.5^{*}$ \\
\hline S. aureus & $18.3 \pm 0.5^{\mathrm{d}}$ & $10.3 \pm 0.5^{\mathrm{c}}$ & $14.3 \pm 0.5^{*}$ \\
\hline B. megaterium & $20.3 \pm 0.5^{\mathrm{d}}$ & $13.3 \pm 1.1^{\mathrm{c}}$ & $13.0 \pm 1.0^{*}$ \\
\hline P.aeruginosa & $20.3 \pm 0.5^{d}$ & $14.0 \pm 1.7^{\mathrm{c}}$ & $12.3 \pm 0.5^{*}$ \\
\hline C.albicans & $9.6 \pm 0.5^{c}$ & $8.3 \pm 0.5^{\mathrm{c}}$ & $12.3 \pm 0.5 * *$ \\
\hline C.glabrata & $9.6 \pm 0.5^{c}$ & $8.3 \pm 0.5^{\mathrm{c}}$ & $9.6 \pm 0.5 * *$ \\
\hline Epidermophyton sp. & $13.6 \pm 1.5^{\mathrm{c}}$ & $9.3 \pm 0.5^{\mathrm{c}}$ & $9.6 \pm 0.5 * *$ \\
\hline Trichophyton sp. & $24.6 \pm 1.5^{\text {cd }}$ & $8.3 \pm 0.5^{\mathrm{a}}$ & $9.6 \pm 0.5 * *$ \\
\hline
\end{tabular}

\begin{tabular}{|c|c|}
\hline \multirow{2}{*}{ Microorganisms } & Inhibition area $(\boldsymbol{\mu L})$ \\
\cline { 2 - 2 } & MIC values \\
\cline { 2 - 2 } E. coli & C. saligna \\
\hline S. aureus & 6.25 \\
\hline B. megaterium & 6.25 \\
\hline P.aeruginosa & 6.25 \\
\hline C. albicans & 6.25 \\
\hline C. glabrata & 12.25 \\
\hline Epidermophyton sp. & 12.25 \\
\hline Trichophyton $\boldsymbol{s p .}$ & 6.25 \\
\hline
\end{tabular}

It is seen that there are studies about antimicrobial and biological activities of different Centaurea species in the literature. Just to clarify, our study is highly significant effect on both dermatophyte fungi and microorganisms by the smallest concentration even.

As Okut et al. [23], stated in their study that the total diameter assessment was called as sensitive, very sensitive and extremely sensitive.

The antimicrobial property of $C$. saligna is high quite against bacteria, yeast and dermatophyta fungi compared to standard antibiotic and methanol and hence it can be a natural antimicrobial agent. However, before revealing their potential as $C$. saligna antimicrobial agents to be used in the pharmaceutical industry, the cytotoxicity of this plant against human cells has been studied. These results are consistent with previous study reports.

On the antimicrobial effect of $C$. saligna a study has been done. It has a preventive effect on $B$. megaterium, E. coli, Proteus vulgaris, B. subtilis, Listeria monocytogenes, Klebsiella pneumoniae, S. aureus, $P$. aeruginosa bacteria and $C$. albicans with a $9-11 \mathrm{~mm}$ zone [24]. The feature that distinguishes our study is that its efficiency at the lowest concentration (MIC) was 
tested and an antidermatophyte effect on Epidermophyton $s p$. and Trichophyton sp. along with other bacteria.

Tekeli et al. [25], It was specified that eight different Centaurea species (MIC value; 8 to $0.0625 \mathrm{mg} / \mathrm{ml}$ ) against E. coli, B. cereus, Salmonella enteritidis and $S$. aureus some indicated inhibitory effect while others did not. Serial dilutions used were prepared as concentrations ranging from 8 to $0.0625 \mathrm{mg} / \mathrm{ml}$. The MIC of $C$. saligna is effective against the growth of $E$. coli and $S$. aureus at a concentration of $6.25 \mathrm{mg} / \mathrm{ml}$.

Bach et al. [26], have stated in their study that the extracts from the weeds $C$. tweediei and $C$. diffusa have antimicrobial (B. subtilis, Rhodococcus aurantiacum and different species of Staphylococci including $S$. aureus, $S$. aureus methicillin-resistant and $S$. epidermidis, E. coli, $P$. aeruginosa and $K$. pneumoniae were used from gramnegative and gram positive isolates) and cytotoxic activities. Although it has cytotoxicity, C. diffusa chloroform extract and cnicin are important in terms of being topically antibiotics against skin-associated pathogens. Compared to the same type of bacteria used in the study, it had a bactericidal effect on bacterial growth in our study. This is due to differences in the amount $\left(25 \mathrm{mg} \mathrm{ml}^{-1}\right)$ and type applied.

Uysal et al. [5], showed that $C$. polyclada DC., $C$. persica Boiss., and $C$. consanguinea DC. ethanol and acetone extracts have preventive effect on the microorganisms. When the effect of $C$. saligna on the bacteria and Candida strains used in the study is compared, the antimicrobial effect of the species used is at the same high level. However, our study differs with the use of Epidermophyton sp. and Trichopyton sp.

In another study, Sarker et al. [27], determined that $C$. persica methanol extract show antimicrobial effect on the E. coli. On the other hand, C. saligna extract showed higher antibacterial properties against $E$. coli proliferation.

In another study; It was observed that three sesquiterpene lactones from $C$. solstitialis L. ssp. solstitialis had antiviral and antimicrobial effects on against both standard and isolated microorganism species. According to the results of the study, three sesquiterpene lactones showed similar low effect against fungi (MIC $1 / 464 \mathrm{mg} \mathrm{ml} \mathrm{-1),} \mathrm{gram} \mathrm{negative} \mathrm{(MIC} \mathrm{1/4} \mathrm{64-}$ $256 \mathrm{mg} \mathrm{ml} \mathrm{-1)}$ ) and gram-positive bacteria (MIC 1/4 64$128 \mathrm{mg} \mathrm{ml} \mathrm{-1).} \mathrm{However,} \mathrm{13-acetyl} \mathrm{solstitialin} \mathrm{A} \mathrm{and,} \mathrm{to}$ a lesser amount, kentaurepensin and chlorojanerin had moderate effect on standard and isolated strains of $\mathrm{S}$. aureus (16 and $32 \mathrm{mg} \mathrm{ml}-1$ values, respectively), which was comparable to AMP (1 and $16 \mathrm{mg} \mathrm{ml}^{-1}$ values, respectively) [2]. $25 \mathrm{mg} \mathrm{ml}^{-1}$ dosage extract of $C$. saligna showed extremely effect and highly antibacterial properties on E. coli and S. aureus.

\section{CONCLUSION}

We believe that this may be due to the different Centaurea species, the different dosage applied and the different proportions of beneficial compounds in the species.

The results of this study revealed the potential of Endemic C. saligna in terms of antimicrobial effect. As a matter of fact, $C$. saligna can be scientific evidence for studies in the field of ethno-pharmacology with this feature. Moreover, By determining the effects of this plant used on microorganisms, it will guide people's traditional usage correctly.

\section{Acknowledgements}

We would like to thank Professor Dr. Sevda Kırbağ at Department of Biology, Firat University for her contribution to our work.

\section{REFERENCES}

[1] Güvensen NC, Keskin D, Güneş H, Oktay MK, Yildırım H. Antimicrobial property and antiproliferative activity of Centaurea babylonica (L.) L. on human carcinomas and cervical cancer cell lines. Ann Agric Environ Med. 2019;26(2):290-297.

[2] Ozcelik B, Gurbuz I, Karaoglu T, Yesilada E. Antiviral and antimicrobial activities of three sesquiterpene lactones from Centaurea solstitialis L. subsp. solstitialis. Microbiol Res. 2009;164:545552.

[3] Khatun S, Parlak KU, Polat R, Cakilcioglu U. The endemic and rare plants of Maden (Elazig) and their uses in traditional medicine. J Herb Med. 2012;2(3):68-75.

[4] Erdogan T, Gonenc T, Cakilcioglu U, Kivcak B. Fatty acid composition of the aerial parts of some Centaurea Species in Elazig. Turkey Trop J Pharm Res. 2014;13(4):613-616.

[5] Uysal I, Çelik S, Sağlam H, Güven K. Antimicrobial and antioxidant activities of Some Species of Centaurea collected from Turkey. Asian J Chem. 2013;25(2):666-670.

[6] Bülent Köse Y, İşcan G, Demirci B, Başer KHC, Çelik S. Antimicrobial activity of the essential oil of Centaurea aladagensis Fitoterapia.2007;78:253254.

[7] Zengin G, Bulut G, Mollica A, Picot-Allain CMN, Mahomoodally MF. In vitro and in silico evaluation of Centaurea saligna (K. Koch) Wagenitz an endemic folk medicinal plant. Comput Biol Chem. 2018; 73:120-126.

[8] Dumlu MU, Gürkan E, Naturforsch Z. A new active compound from Centaurea species. Z Naturforsch C. 2005; 61: 44-46.

[9] Koca U, Pesin Süntar I, Keles H, Yesilada E, Küpeli Akkol E. In vivo anti-inflammatory and wound healing activities of Centaurea iberica Trev. ex Spreng. J Ethnopharmacol. 2009;126(3):551556. 
[10] Kubacey TM, Haggag EG, El-Toumy SA, Amany AA, El-Ashmawy IM, Youns MM. Biological activity and flavonoids from Centaurea alexanderina leaf extract. $\mathrm{J}$ Pharm Res. 2012;5(6):3352-3361.

[11] Albayrak S, Atasagun B, Aksoy A. Comparison of phenolic components and biological activities of two Centaurea sp. obtained by three extraction techniques. Asian Pac J Trop Med. 2017;10(6):599606.

[12] Baykan Erel S, Demir S, Nalbantsoy A, Ballar P, Khan S, Karaalp C, et al. Cytotoxic, antioxidant, antiinfammatory capacities of five Centaurea L. species and in vivo antiinflammatory evaluation of Centaurea athoa. 10th ISOPS. Ankara; 2012.

[13] Zater H, Huet J, Fontaine V, Benayache S, Stevigny C, Duez P, et al. Chemical constituents, cytotoxic, antifungal and antimicrobial properties of Centaurea diluta Ait. sub sp. algeriensis (Coss. \& Dur.) Maire. Asian Pac J Trop Med. 2016;9(6):554-561.

[14] Şen A, Bitiş L, Birteksöz-Tan S, Bulut G. In vitro evaluation of antioxidant and antimicrobial activities of some Centaurea L. species. J Pharm Res.2013;1:42-45.

[15] Koukoulitsa E, Skaltsa H, Karioti A, Demetzos C. Bioactive sesquiterpene lactones from Centaurea species and their cytotoxic/cytostatic activity against human cell lines in vitro. Planta Med. 2002;68(7):649-52.

[16] Kilic O. Essential oil compounds of three Centaurea L. taxa from Turkey and their chemotaxonomy. J M Plant Res. 2013;7(19):13441350.

[17] Riham OB, Shaza AEHM, Nahla A. Phenolic profile of Centaurea aegyptiaca L. growing in Egypt and its cytotoxic and antiviral activities. Afr JT radit Complement Altern Med. 2016;13(6):135143.

[18] Panagouleas C, Skaltsa H, Lazari D, Skaltsounis A, Sokovic A. Antifungal activity of secondary metabolites of Centaurea raphanina subsp. mixta, growing wild in Greece. Pharm Biol. 2003;41(4):266-270.

[19] Barry L, Hainer, MD. Dermatophyte infections. Am Fam Physician. 2003;67(1):101-109.

[20] Davis PH. Flora of Turkey and the Aegean Islands. V: 7, 8, 9. England: Edinburgh Univ. Press;19701984-1985.

[21] Collins CH, Lyne PM. Microbiological methods. London: Butter worths \& Co. (Publishers) Ltd; 1989. p. 410.

[22] Güllüce $M$, Adigüzel A, Oğütçü H, Şengül $M$, Karaman I, Şahin F. Antimicrobial effects of Quercus L. extract. Phytother Res. 2004;18(3):208211.

[23] Okut N, Yıldırım B, Ekici K, Terzioğlu Ö, Özgökçe F. Identification of chemical composition and antibacterial properties Juniperus oxycedrus L. subsp. oxycedrus leaf essential oil. Y Y U J Agr Sci. 2018;28(2):186-191.

[24] Keser S, Keser F, Türkoğlu İ, Kaygılı Ö, Tekin S, Demir E, et al. In vitro biological evaluation and phytochemical contents of three Centaurea L. species growing from Eastern Anatolia in Turkey. KSÜ J Agr Nat. 2020;23(1):148-156.

[25] Tekeli Y, Zengin G, Aktumsek A, Sezgin M, Torlak E. Antibacterial activities of extracts from twelve Centaurea species from Turkey. Arch Biol Sci Belgrade. 2011;63(3):685-690.

[26] Bach SM, Fortuna MA, de Trimarco ARJT, Catalan CAN, Av-Gay Y, Bach H. Antibacterial and cytotoxic activities of the sesquiterpene lactones cnicin and onopordopicrin. Nat Prod Commun. 2011;6(2):163-166.

[27] Sarker Satyajit D, Nahar L, Gujja S, Begum S, Celik S. Bioactivity of Centaurea persica Boiss. (Asteraceae). Arch Biol Sci 2012;64(2):517-523. 